\title{
Select biological characteristics of the mossul bleak Alburnus mossulensis Heckel, 1843 (Actinopterygii: Cyprinidae) in the Ataturk Dam Lake, Turkey
}

\author{
ARIF PARMAKSIZ ${ }^{1}$, AHMET OYMAK ${ }^{2}$, NECMETTIN DOGAN ${ }^{3}$ AND ERHAN UNLU ${ }^{4}$ \\ ${ }^{1}$ Department of Biology, Faculty of Science-Literature, Harran University, Sanliurfa - 63100, Turkey \\ ${ }^{2}$ Department of Mathematics and Science Education, Faculty of Ataturk Education, Marmara University \\ Istanbul - 34730, Turkey \\ ${ }^{3}$ Bilgi Anatolian High School, Adiyaman - 02100, Turkey \\ ${ }^{4}$ Department of Biology, Faculty of Science-Literature, Dicle University, Diyarbakir - 21100, Turkey \\ e-mail: aprmksz@gmail.com
}

\section{ABSTRACT}

\begin{abstract}
Maturity, growth and reproductive characteristics of the mossul bleak Alburnus mossulensis, from Ataturk Dam Lake (Euphrates) were assessed. Maturity composition of the analysed samples varied between age groups I and VII. The ratio of females to males was 1.047:1. Fork length of the samples varied between 40-198 mm and weights were in the range of 0.45-68 g. The regression equations derived for the length-weight relationship was $\log \mathrm{W}=-5.5531+3.2958 \mathrm{Log} \mathrm{FL}$ $(\mathrm{r} 2=0.9593)$ for females and $\log \mathrm{W}=-5.3695+3.2112 \log \mathrm{FL}(\mathrm{r} 2=0.9487)$ for males. Mean condition factor was determined as 1.069 for females and 1.062 for males. Absolute fecundity was established to be between 288 and 3380 . The age of sexual maturity was 3 years in females and 2 years in males.
\end{abstract}

Keywords: Alburnus mossulensis, Ataturk Dam Lake, Euphrates River, Growth, Maturity, Mossul bleak

\section{Introduction}

The mossul bleak Alburnus mossulensis Heckel, 1843 (Family: Cyprinideae) is widely distributed throughout Tigris and Euphrates river basins, Turkey and Syria (Kuru, 1979; Bogutskaya, 1997; Coad, 2010) and it is one of the commercially significant freshwater fish species in Ataturk Dam Lake (Oymak, 2000; Duman and Celik, 2001; Bayhan and Gocer, 2012). This species is found both in lentic and lotic environments (Unlu, 2014).

Despite being a small fish, A. mossulensis is commercially important in the region. Since it is a fast growing fish and an indiscriminate feeder (Coad, 2010), it can be a good source of inexpensive animal protein. This fish also has the potential to be used as a source of fish feed in aquaculture. Several studies have been done on the biology of $A$. mossulensis in Iraq (Barak, 1978; Jawad, 2004), Iran (Esmaeili and Ebrahimi, 2006; Parsa et al., 2011; Mousavi-Sabet et al., 2013) and Turkey (Ergene, 1993; Ozdemir et al., 1993; Turkmen and Akyurt, 2000; Yıldırım et al., 2003; Basusta and Cicek, 2006; Yildirim et al., 2007; Uckun and Gokce, 2014). However, there is not much documentation on the biological characteristics of this species in the Atatürk Dam Lake.

The aim of this study was to provide information about age, growth and condition factor, age at sexual maturity, spawning period and fecundity of this species from the Atatürk Dam Lake, which is one of the biggest dam lakes in the world.

\section{Materials and methods}

Ataturk Dam, with its 84.5 million $\mathrm{m}^{3}$ fill volume and $169 \mathrm{~m}$ height above the foundation, is the sixth largest dam in the world in terms of fill volüme (Agan, 2016). It is located on the Euphrates River in south-east Anatolia, Turkey (Fig. 1). About 35 species constantly dwell the dam lake (Bozkurt, 1994). Alburnus mossulensis (Heckel, 1843); Cyprinus carpio (Linnaeus, 1758); Acanthobrama marmid (Heckel, 1843); Liza abu (Heckel, 1843); Chondrostoma regium (Heckel, 1843); Capoetta trutta (Heckel, 1843); Carasobarbus luteus (Heckel, 1843); Mastacembelus mastacembelus (Banks andSolander, 1794); Cyprinion macrostomus (Heckel, 1843); Arabibarbus grypus (Heckel, 1843) and Luciobarbus mystaceus (Pallas, 1814) are the main commercial fishes in the dam lake (Bozkurt, 1994; Oymak, 2000).

A total of 301 specimens were caught between October 2008 and September 2009 using sinking horizontal gillnets (100 m long, $2 \mathrm{~m}$ high and mesh size of 12 and $24 \mathrm{~mm}$ ). Specimens were immediately transported to the laboratory in a portable icebox. Fish were identified 


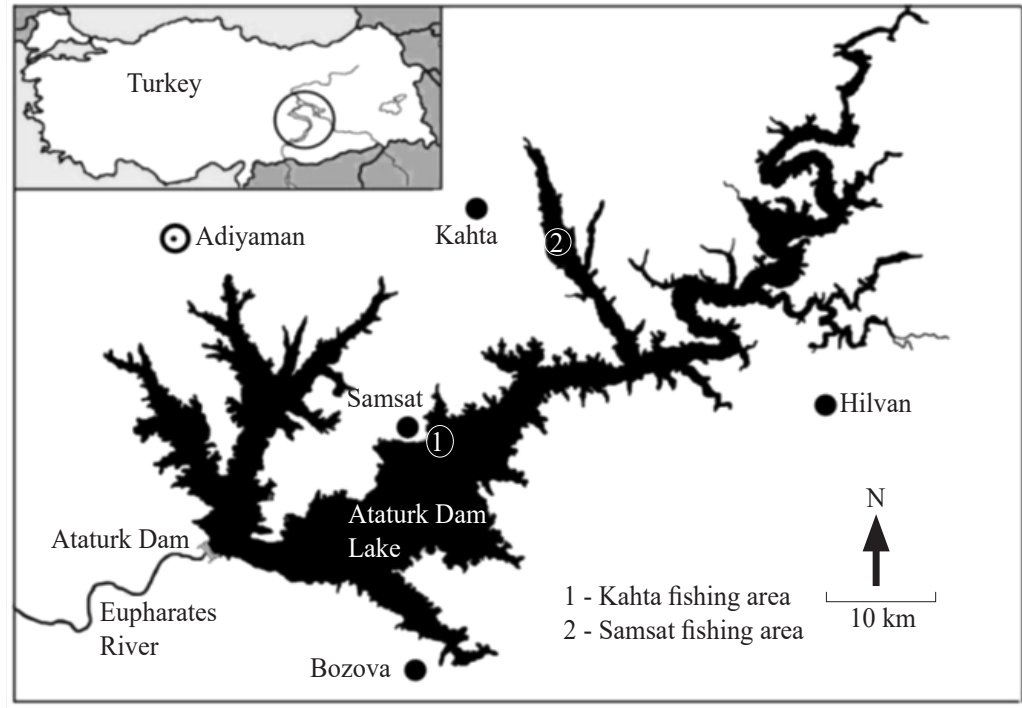

Fig. 1. Map of the study area (Oymak et al., 2011)

to species level with the identification keys given by Kuru (1980).

Fork length (FL), weight (W) and gonad weight (GW) were measured to an accuracy of $1 \mathrm{~mm}, 1 \mathrm{~g}$ and $0.01 \mathrm{~g}$, respectively. Sex in mature specimens was determined by visul examination of gonads, but microscopic examination was used for differentiating sex in juveniles (Unlu, 1991). The statistical significance of the sex ratio results was established by Chi-squared test $\left(\chi^{2}\right)$. Differences were considered statistically significant at $\mathrm{p}<0.05$. Age was determined from scales (Ekingen and Polat, 1987). For this purpose, approximately 10 scales from each fish were mounted between two glass microscope slides and they were assessed by Kindermann microfiche reader. Maturity of samples was determined monthly by internal examination.

The formula $\mathrm{L}_{\mathrm{t}}=\mathrm{L} \infty\left[1-\mathrm{e}^{-\mathrm{k}(\mathrm{t}-\mathrm{t})}\right]$ was used to describe the age-length relationship. Length-weight regression was carried out by the least squares method on logarithmic converted data by the equation $\mathrm{W}=\mathrm{aL}^{\mathrm{b}}$ (Le Cren, 1951; Tesch, 1968; Ricker, 1968). Analyses of variance (ANOVA) was done to detect the statistical significance between the length-weight relationship of male and female. Condition factor was assessed using the formula $\mathrm{K}=\mathrm{Wx}$ 105/L3 (Tesch, 1968). One-way ANOVA was used to test the similarity in condition index between months. Statistical differences between females and males in condition index was sudied using Student's t-test. The average age at which $50 \%$ of fishes mature was taken to be the age at first maturity (Oymak et al., 2011) and the length corresponding to this age was taken as the length at first maturity.
The monthly gonado-somatic index (GSI) was calculated using the formula given by Tesch (1968) to identify the spawning period:

\section{$\mathrm{GSI}=G W \times 100 / W-G W$}

where $W=$ body weight, $G W=$ gonad weight.

Absolute fecundity was estimated gravimetrically (Laevastu, 1965) from samples drawn from mature ovaries during the spawning season (April and May). Regression equations describing relationships between fecundity (F) and fork length (FL), fecundity and body weight (W) and fecundity and gonad weight $(\mathrm{GW})$ were calculated using the following formula:

$\log \mathrm{F}=\log \mathrm{a}+\mathrm{b} \log \mathrm{FL} ; \log F=\log \mathrm{a}+\mathrm{b} \log \mathrm{W} ; \log \mathrm{F}=\log \mathrm{a}+\mathrm{b}$ $\log \mathrm{GW}$;

where $\mathrm{F}=$ number of eggs, $\mathrm{L}=$ fork length $(\mathrm{mm})$, $\mathrm{W}=$ body length $(\mathrm{g})$ and $\mathrm{GW}=$ gonad weight $(\mathrm{g})$ (Unlu et al., 1994; Oymak et al., 2011).

\section{Results and discussion}

\section{Age and sex composition}

In this study, 154 females and 147 males (301 in total) were examined. The overall ratio of females to males was found to be 1.05:1 and $\chi^{2}$ analysis showed that this was not statistically significant $\left(\chi^{2}=0.162, \mathrm{p}>0.05\right)$.

Age of the fish ranged from 1 to 7 years. Age group IV was the dominant age group for both sexes (Table 1). In two separate studies, in the Karasu River, the age groups were defined to be I-V and I-VII for Chalcalburnus mossulensis, a synonym of the species A. mossulensis (Turkmen and Akyurt, 2000; Yildirim et al., 2003) and in Karakaya Dam Lake, age groups of 0-IV (Uckun and Gokce, 2014) were established for A. mossulensis. 
Table 1. Age distribution of A. mossulensis from Ataturk Dam Lake, Turkey ( $\mathrm{N}=$ number of specimens)

\begin{tabular}{|c|c|c|c|c|c|c|}
\hline \multirow{2}{*}{ Age Groups } & \multicolumn{2}{|c|}{ Female } & \multicolumn{2}{|c|}{ Male } & \multicolumn{2}{|c|}{ Total } \\
\hline & $\mathrm{N}$ & $\%$ & $\mathrm{~N}$ & $\%$ & $\mathrm{~N}$ & $\%$ \\
\hline I & 1 & 0.33 & 4 & 1.33 & 5 & 1.66 \\
\hline II & 0 & 0 & 26 & 8.64 & 26 & 8.64 \\
\hline III & 10 & 3.32 & 28 & 9.3 & 38 & 12.62 \\
\hline IV & 95 & 31.56 & 74 & 24.59 & 169 & 56.15 \\
\hline $\mathrm{V}$ & 35 & 11.63 & 13 & 4.32 & 48 & 15.95 \\
\hline VI & 11 & 3.65 & 2 & 0.66 & 13 & 4.32 \\
\hline VII & 2 & 0.66 & 0 & 0 & 2 & 0.66 \\
\hline Total & 154 & 51.15 & 147 & 48.85 & 301 & 100 \\
\hline
\end{tabular}

\section{Length and weight composition}

The length distribution of the species was 40-198 $\mathrm{mm}$ and the majority of the fishes measured 150-175 mm (Fig. 2). Weight of $A$. mossulensis samples ranged between 0.45 and $68 \mathrm{~g}$ and the majority weighed $30-50 \mathrm{~g}$ (Fig. 2).

In two separate studies from the Karasu River, the fork lengths were in the range $85-185 \mathrm{~mm}$ and 94-195 mm (Turkmen and Akyurt, 2000; Yildirim et al., 2003), while the total lengths of individual specimens in Ataturk Dam Lake were 83-242 mm (Basusta and Cicek, 2006). Fork lengths of the species reported in Iran were 36-93 mm (Esmaeili and Ebrahimi, 2006) and the total lengths reported from Gamasiab River were 70-155 mm (Mousavi-Sabet et al., 2013) while the values in Karakaya Dam Lake were found to be between 108-190 mm (Uckun and Gokce, 2014). The difference in the size range in different localities is attributed to the changes in the biotic and abiotic factors between the environments and fishing periods (Emmrich et al., 2014). In our study, the weight of the individual specimens ranged between 0.45-68 g. In studies from different localities, including two separate studies in the Karasu River, the values recorded were

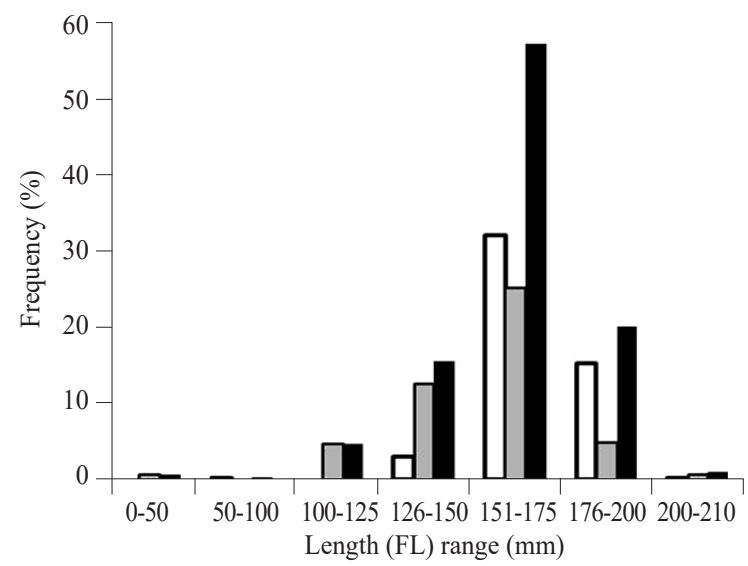

달, $\square$ Male, $\square \mathrm{F}+\mathrm{M}$

Fig. 2. Length and weight composition of A. mossulensis from Ataturk Dam Lake
3.64-79.5 g and 67.93-86.5 g (Turkmen and Akyurt, 2000; Yildirim et al., 2003). The weight of individual specimens in Gamasiab River were between 6.3-54.6 g (MousaviSabet et al., 2013). Individual specimens in Karakaya Dam Lake have been identified to vary in weight between 16.87-56.57 g (Uckun and Gokce, 2014).

\section{Growth in length}

The length values of $A$. mossulensis calculated for each age group are summarised in Table 2

The lemgth-at-age equations of $A$. mossulensis calculated according to von Bertalanffy, for females, males and sexes combined were:

Female $\quad: \mathrm{L}_{\mathrm{t}}=235.69\left[1-\mathrm{e}^{-0.21742(\mathrm{t}-(-1.4271))}\right]$

Male $\quad: \mathrm{L}_{\mathrm{t}}=205.293\left[1-\mathrm{e}^{-0.47692(\mathrm{t}-0.03757)}\right]$

Sexes pooled $\quad: \quad \mathrm{L}_{\mathrm{t}}=207.544\left[1-\mathrm{e}^{-0.3966(\mathrm{t}-(-0,0078))}\right]$

It was estimated that the females had higher $\mathrm{L} \infty$ (235.69 $\mathrm{mm})$ and lower low $\mathrm{K}(0.21742)$ values than males $(\mathrm{L} \infty=205.293 \mathrm{~mm}$ and $\mathrm{K}=0.47692)$. The agelength relationship curve of $A$. mossulensis is shown in Fig. 3.

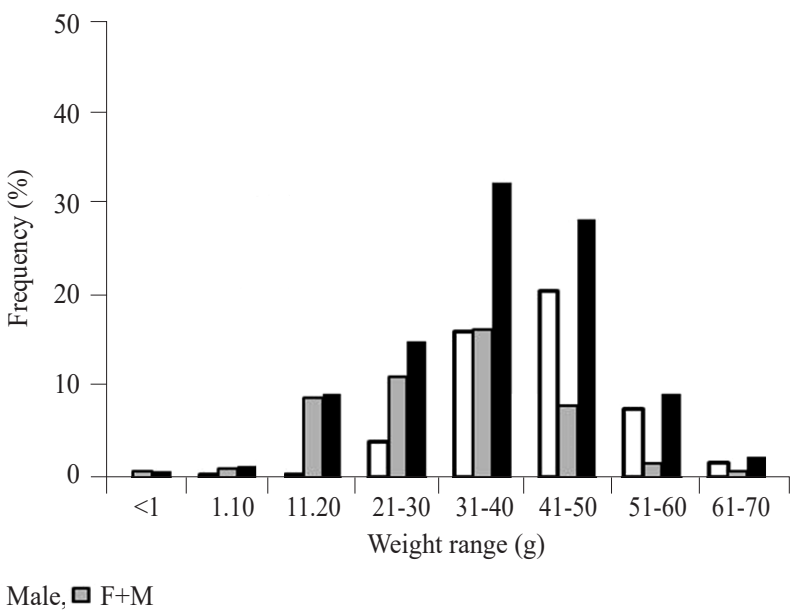


Table 2. Length (mm) of $A$. mossulensis from the Ataturk Dam Lake

\begin{tabular}{|c|c|c|c|c|c|c|}
\hline \multirow{2}{*}{ Age groups } & \multicolumn{2}{|r|}{ Female } & \multicolumn{2}{|r|}{ Male } & \multicolumn{2}{|c|}{ Statistical differences between sexes } \\
\hline & $\mathrm{N}$ & Mean \pm SD (min-max) & $\mathrm{N}$ & $\operatorname{Mean} \pm \mathrm{SD}(\min -\max )$ & Student's t-test & $\mathrm{p}$ \\
\hline $\bar{I}$ & 1 & 8 & 4 & $73.00 \pm 35.29(40-105)$ & & \\
\hline II & - & - & 26 & $128.58 \pm 10.00(110-150)$ & & \\
\hline III & 10 & $149.6 \pm 9.92(140-170)$ & 28 & $147.86 \pm 10.33(125-162)$ & 0.3812 & 0.3527 \\
\hline IV & 95 & $165.62 \pm 8.81(150-195)$ & 74 & $163.74 \pm 8.39(145-182)$ & 1.4041 & 0.0811 \\
\hline $\mathrm{V}$ & 35 & $179.17 \pm 7.12(163-193)$ & 13 & $187.69 \pm 7.33(175-205)$ & -3.6566 & $0.0003 *$ \\
\hline VI & 11 & $191.5 \pm 8.58(175-205)$ & 2 & $196.50 \pm 12.02(188-205)$ & -0.9451 & 0.1824 \\
\hline VII & 2 & 198 & - & - & & \\
\hline
\end{tabular}

${ }^{*}=$ Significantly different $(\mathrm{p}<0.05)$

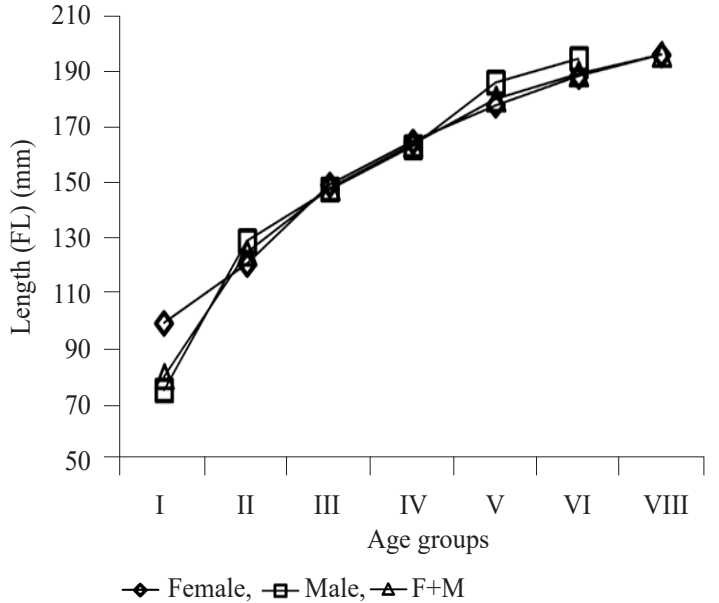

Fig. 3. Age-length relationship curves of A. mossulensis in Ataturk Dam Lake

Growth in weight

The weights in the different age groups of A. mossulensis with their absolute growth in weight are given in Table 3 . The differences in weight are statistically significant between females and males of age group IV $(p<0.001)$, while in the other age groups the differences are not statistically significant $(\mathrm{p}>0.05)$.

\section{Length-weight relationship}

The length-weight equations were derived as: Female $: \log \mathrm{W}=-5.5531+3.2958 \log \mathrm{FL}\left(\mathrm{r}^{2}=0.9593\right)$

Male $\quad: \log \mathrm{W}=-5.3695+3.2112 \log \mathrm{FL}\left(\mathrm{r}^{2}=0.9487\right)$

Sexes pooled $\mathrm{F}+\mathrm{M}: \log \mathrm{W}=-5.4953+3.2695 \log \mathrm{FL}$ $\left(r^{2}=0.9563\right)$

The " $b$ " values of both sexes indicated positive allometric growth. The curves of the length-weight relationship obtained from these equations are shown in Fig. 4.

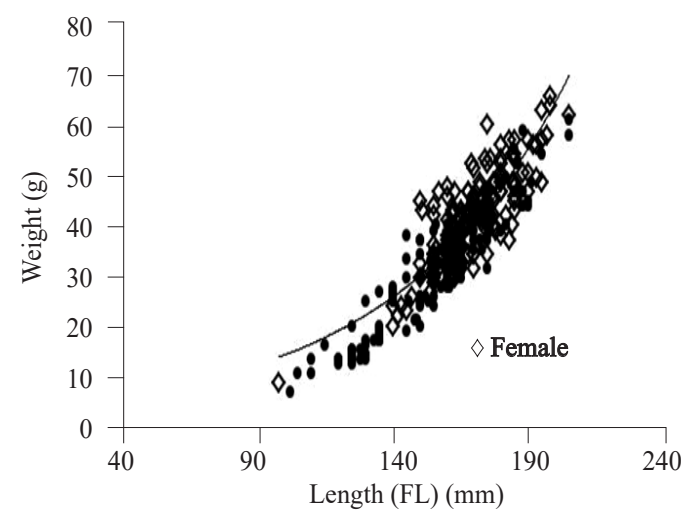

Fig. 4. Length-weight relationship of A. mossulensis from Ataturk Dam Lake

Table 3. Weight (g) of A. mossulensis from the Ataturk Dam Lake

\begin{tabular}{|c|c|c|c|c|c|c|}
\hline \multirow[b]{2}{*}{ Age groups } & \multicolumn{2}{|r|}{ Female } & \multicolumn{2}{|r|}{ Male } & \multicolumn{2}{|c|}{ Statistical differences between sexes } \\
\hline & $\mathrm{N}$ & Mean \pm SD (min-max) & $\mathrm{N}$ & Mean \pm SD (min-max) & Student's t-test & $\mathrm{p}$ \\
\hline I & 1 & 8 & 4 & $4.24 \pm 4.64(0.45-10)$ & & \\
\hline II & - & - & 26 & $15.27 \pm 2.81(10-21)$ & & \\
\hline III & 10 & $25.90 \pm 4.33(20-35)$ & 28 & $25.54 \pm 3.11(17-30)$ & 0.2862 & 0.3882 \\
\hline IV & 95 & $39.56 \pm 5.70(30-54)$ & 74 & $36.70 \pm 4.74(29-48)$ & 3.4723 & $0.0003 *$ \\
\hline $\mathrm{V}$ & 35 & $50.14 \pm 3.15(45-56)$ & 15 & $50.62 \pm 5.52(45-63)$ & -0.3721 & 0.3558 \\
\hline VI & 11 & $60.09 \pm 2.47(58-65)$ & 2 & $60.50 \pm 0.71(60-61)$ & -0.2252 & 0.4130 \\
\hline VII & 2 & $67 \pm 1.41(66-68)$ & - & - & & \\
\hline
\end{tabular}

\footnotetext{
$"=$ Significantly different $(\mathrm{p}<0.05)$
} 


\section{Condition factor}

The condition factor of $A$. mossulensis ranged between 0.4478 and 1.4770 in females and between 0.1866 and 1.4893 in males (Table 4). The differences in condition factor between sexes in the same age group were not statistically significant between the individuals of age groups ( $\mathrm{p}>0.05)$ except age groups IV and V $(\mathrm{p}<0.05)$.

In terms of monthly changes in condition factor, significant differences were seen between the months for both females (ANOVA, $\mathrm{F}=9.8181, \mathrm{p}=0.000$ ) and males (ANOVA, $F=17.8585, p=0.000$ ). The values for both sexes were highest in April and lowest in December (Fig. 5).

The mean condition factor of $A$. mossulensis in Karasu River was calculated as 1.047 for females and 1.023 for males (Turkmen and Akyurt, 2000). The condition factor of the same species in the Gamasiab River was between 0.20 to 2.51 for females and 0.32 to 2.01 for males (MousaviSabet et al., 2013). Average condition factors in specimens in Karakaya Dam Lake were found to be $0.90 \pm 0.1$ for females and $0.84 \pm 0.11$ for males (Uckun and Gokce, 2014). The condition factor of $A$. mossulensis species shows significant similarities compared to other species, such as Alburnus esherichii (Cetinkaya et al., 2015) and A. alburnus (Stavrescu-Bedivan et al., 2017). The condition factor is an index reflecting interaction between biotic and abiotic factors in the physiological conditions of fishes (Nikolsky, 1963).

In our study, the values of condition factor for both sexes were highest in April, and lowest in December. This value in the Karasu River however, was at its highest level between March and May; it declined in June because of spawning times and was lowest in December (Turkmen and Akyurt, 2000). In the Gamasiab River it was highest in May and lowest in August (Mousavi-Sabet et al., 2013); in the Karakay Dam Lake it was identified to be highest in May and lowest in September (Uckun and Gokce, 2014). Condition factor values showed a parallel increase with progressive gonad development and positively correlated with increase in gonad weight.

\section{Age and size at first maturity}

The age at sexual maturity of $A$. mossulensis was $2+$ in males (Table 5). Due to lack of female specimens in the $2+$ age group, the age at sexual maturity in female A. mossulensis could not be assessed. However, all samples at age 3 and over were found to be mature. The mean fork length of mature males was $128.6 \mathrm{~mm}$ and $149.6 \mathrm{~mm}$ in females. The mean weight of males was $15.27 \mathrm{~g}$ and $25.90 \mathrm{~g}$ in females.

Table 4. Condition factor of the different age groups of A. mossulensis from Ataturk Dam Lake

\begin{tabular}{|c|c|c|c|c|c|c|}
\hline \multirow[t]{2}{*}{ Age groups } & \multicolumn{2}{|r|}{ Female } & \multicolumn{2}{|r|}{ Male } & \multicolumn{2}{|c|}{ Differences between female and male } \\
\hline & $\mathrm{N}$ & Mean \pm SD (min-max) & $\mathrm{N}$ & Mean \pm SD (min-max) & Student's t test & $\mathrm{p}$ \\
\hline I & 1 & 0.8499 & 4 & $0.5583 \pm 0.2633(0.1866-0.7815)$ & 0.5237 & 0.3464 \\
\hline II & - & - & 26 & $0.7237 \pm 0.1716(0.2791-1.2021)$ & & \\
\hline III & 10 & $0.6381 \pm 0.1365(0.4478-0.8017)$ & 28 & $0.8363 \pm 0.1617(0.6445-1.2800)$ & -0.6428 & 0.2621 \\
\hline IV & 95 & $0.9210 \pm 0.3726(0.5107-4.2499)$ & 74 & $0.8416 \pm 0.1475(0.4316-1.2793)$ & 1.6871 & $0.0467^{*}$ \\
\hline $\mathrm{V}$ & 35 & $0.8974 \pm 0.1563(0.6998-1.4770)$ & 13 & $0.8146 \pm 0.1006(0.6707-1.0000)$ & 3.5043 & $0.0005^{*}$ \\
\hline VI & 11 & $0.9498 \pm 0.1603(0.7429-1.2009)$ & 2 & $1.0929 \pm 0.5606(0.6965-1.4893)$ & 0.8160 & 0.2159 \\
\hline VII & 2 & $0.8211 \pm 0.0777(0.7661-0.8760)$ & - & - & & \\
\hline
\end{tabular}

"= Significantly different $(\mathrm{p}<0.05)$
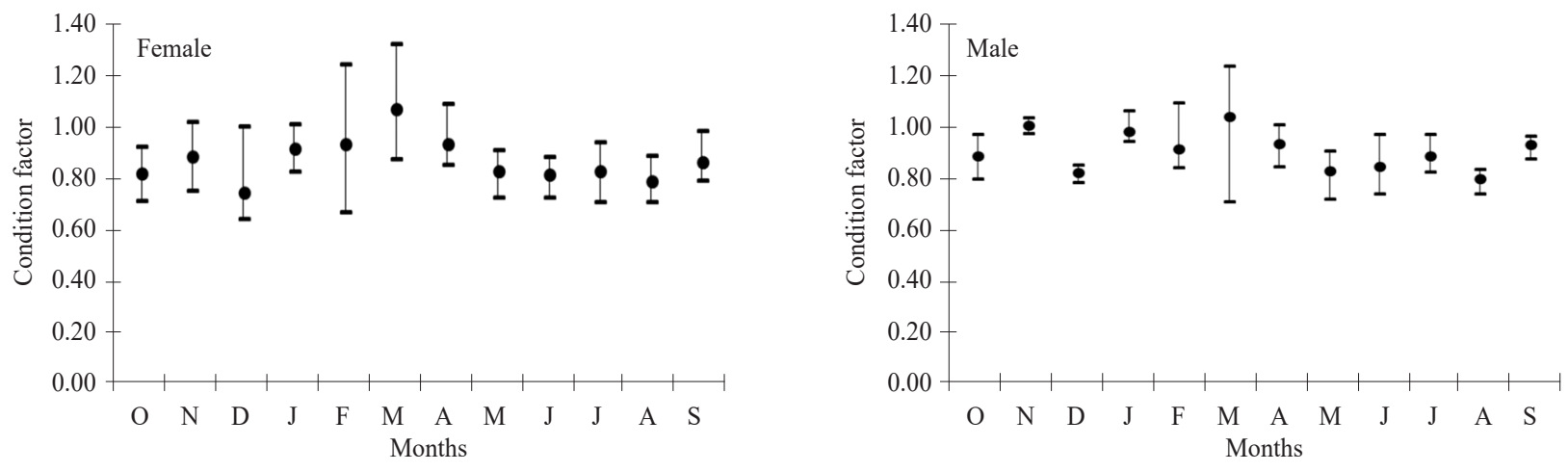

- Mean, - Min-Max

Fig. 5. Annual cycle of condition factor of $A$. mossulensis from Ataturk Dam Lake between October 2008 and September 2009 
Table 5. The age at maturity of females and males of $A$. mossulensis from Ataturk Dam Lake

\begin{tabular}{|c|c|c|c|c|c|c|c|c|}
\hline & & I & II & III & IV & V & VI & VII \\
\hline \multirow[t]{4}{*}{ Female } & Immature & 1 & - & 0 & 0 & 0 & 0 & 0 \\
\hline & $\%$ & 100 & - & 0 & 0 & 0 & 0 & 0 \\
\hline & Mature & - & - & 10 & 95 & 35 & 11 & 2 \\
\hline & $\%$ & 0 & - & 100 & 100 & 100 & 100 & 100 \\
\hline \multirow[t]{4}{*}{ Male } & Immature & 4 & 1 & 0 & 0 & 0 & 0 & 0 \\
\hline & $\%$ & 100 & 3.85 & 0 & 0 & 0 & 0 & 0 \\
\hline & Mature & - & 25 & 28 & 74 & 13 & 2 & 2 \\
\hline & $\%$ & - & 96.15 & 100 & 100 & 100 & 100 & 100 \\
\hline
\end{tabular}

Spawning season

Identification of the spawning season of A. mossulensis population in Ataturk Dam Lake was done based on the gonado-somatic index (GSI) values, analysis of development in mean egg diameter and direct observation of the gonads (Fig. 6). There was marked individual variation in the pattern of monthly GSI values; high values were observed in the samples caught in the spring months, i.e., March, April and May, while in June, there was a decrease in the GSI values since most of the individuls spawned in May. In Karakaya Dam Lake, GSI values were found to be highest in May, with the lowest value in October for males and December for females (Uckun and Gokce, 2014).

The mean egg diameter was highest in April and lowest in August, when the ovaries comprised only developing oocytes (Fig. 6). Based on these observations it was concluded that the species is ready for reproductive activity from April and peak spawning period of A. mossulensis population in Ataturk Dam Lake was in May.

Fecundity

Absolute fecundity in A. mossulensis was found to be low and ranged from 288 to 3380 . A positive correlation was determined between fecundity and fish length, fish weight and gonad weight, and the regression equations derived are given below:

$$
\begin{array}{lll}
\log F=-0.103+1.771 \log F L & r^{2}=0.467 & p>0.05 \\
\log F=-2.539+0.668 \log W & r^{2}=0.524 & p<0.05 \\
\log F=-4.516+0.215 \log G W & r^{2}=0.265 & p<0.05
\end{array}
$$

It is well known that fecundity is affected by age, size, feeding, season and environmental conditions (Hanson,

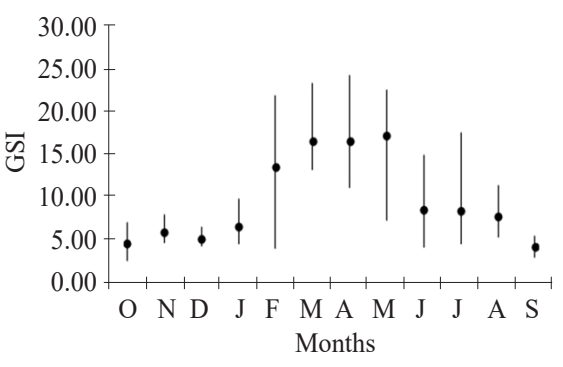

(a)

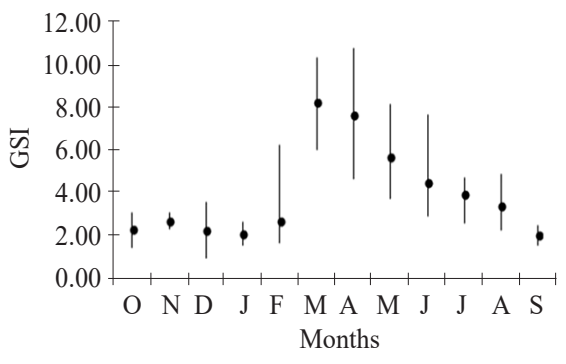

(b)

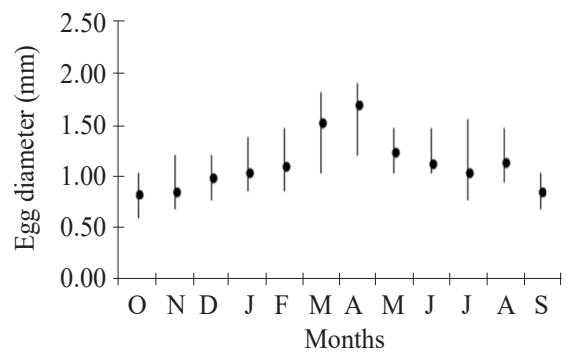

(c)

Fig. 6. Annual GSI (a: Female, b: Male) and egg diameter (c) of A. mossulensis from Ataturk Dam Lake between October 2008 and September 2009

2009). Fecundity recorded in the present study was much lower than that reported by Yildirim et al. (2007) in Karasu River (3000-11000) and by Keivany et al. (2017b) in Bibi-Sayyedan River in Iran (2000-10000).

\section{Acknowledgements}

This study was supported by Harran University, Scientific Research Commission Project (HUBAK: 819). The authors report no conflicts of interest.

\section{References}

Agan, C. 2016. Prediction of squeezing potential of rock masses around the Suruc water tunnel. Bull. Eng. Geol. Environ., 75: 451-468. DOI:10.1007/s10064-015-0758-1.

Barak, N. A. A. 1978. Food habits of three Iraqi fishes, Aphanius dispar (Ruppell), Liza abu (Heckel) and Alburnus mossulensis (Heckel), in Al-Saklawiah irrigation drainage system. M. Sc. Thesis, University of Baghdad. 147 pp.

Basusta, N. and Cicek, E. 2006. Length-weight relationships for some teleost fishes caught in Ataturk Dam Lake on 
south-eastern Anatolia, Turkey. J. Appl. Ichthyol., 22: 279-280. DOI: $10.1111 /$ j.1439-0426.2006.00778.x.

Bayhan, Y. K. and Gocer, M. 2012. The fisheries in Ataturk Dam Lake (Adiyaman) and technical features of the fishing gears being used. J. Fish. Sci., 6: 232-242.

Bogutskaya, N. G. 1997. Contribution to the knowledge of leuciscine fishes of Asia Minor. Part 2. An annotated check-list of leuciscine fishes (Leuciscinae, Cyprinidae) of Turkey with descriptions of a new species and two new subspecies. Mitt. Hamb. Zool. Mus. Inst., 94: 161-186.

Bozkurt, R. 1994. Ataturk Baraj Golu ve baraj golune dokulen derelerdeki balıkların sistematigi. M. Sc. Thesis, University of Harran, 71 pp.

Cetinkaya, S., Yegen, V., Bilgin, F., Uysal, R. and Bostan, H. 2015. Variations of some growth characteristics and length-length relationships of sakarya bleak (Alburnus esherichii Steindachner, 1897) in different habitats. J. Limnol. Freshw. Fish. Res., 1(1): 29-35. doi.org/10. 17216/LimnoFish-5000087074.

Coad, B. W. 2010. Freshwater fishes of Iraq. Pensoft Publishers, Sofia-Moscow, $294 \mathrm{pp}$

Duman, E. and Celik, A. 2001. Ataturk Baraj Golu Bozova Bolgesi'nde avlanan balıklar ve verimlilikleri. Ege Universitesi Su Urünleri Dergisi, 18: 65-69.

Ekingen, G. and Polat, N. 1987. Age determination and lengthweight relations of C. C. umbla (Heckel) in Lake Keban. Turkish J. Zool., 11(12): 5-15.

Emmrich, M., Pedron, S., Brucet, S., Winfield, I. J., Jeppesen, E., Volta,P.,Argillier, C.,Lauridsen, T., Holmgren,K., Mehner, T. and Hesthagen, T. 2014. Geographical patterns in the body size structure of European lake fish assemblages along abiotic and biotic gradients. J. Biogeogr., 41(12): 2221-2233. doi.org/10.1111/jbi.12366.

Ergene, S. 1993. Karasu'da Yaşayan Chalcalburnus mossulensis (Heckel, 1843), (Pisces, Cyprinidae)' in Buyume Oranları. Turkish J. Zool., 17(4): 367-377.

Esmaeili, H. R. and Ebrahimi, M. 2006. Length-weight relationships of some freshwater fishes of Iran. J. Appl. Ichthyol., 22(4): 328-329. doi.org/10.1111/j.1439-0426.20 06.00653.x

Hanson, N. 2009. Population level effects of reduced fecundity in the fish species perch (Perca fluviatilis) and the implications for environmental monitoring. Ecol. Model., 220(17): 2051-2059. DOI: 10.1016/j.ecolmodel.2009.04.053.

Innal, D. 2010. Population structures and some growth properties of three cyprinid species [Squalius cephalus (Linnaeus, 1758); Tinca tinca (Linnaeus, 1758) and Alburnus escherichii Steindachner, 1897] living in Camkoru Pond (Ankara-Turkey). Journal of the Faculty of Veterinary Medicine, University of Kafkas, 16 (Suppl.): 297-304.
Jawad, L. A. J. 2004. Preliminary study on the use of eye lens diameter and weight as an age indicator in two cyprinid fishes collected from Basrah, Iraq. Bollettino del Museo Regionale di Scienze Naturali di Torino, 21(1): 151-158.

Keivany, Y., Ghorbani, M. and Paykan-Heyrati, F. 2017a. Age and growth of Alburnus mossulensis (Cyprinidae) in BibiSayyedan River of Isfahan Province. Iranian J. Fish. Sci., 16(4): 1164-1177.

Keivany, Y., Ghorbani, M. and Paykan-Heyrati, F. $2017 \mathrm{~b}$. Reproductive biology of Mossul bleak (Alburnus mossulensis) in Bibi-Sayyedan River of Tigris basin in Iran. Caspian J. Environ. Sci., 15(2): 135-145.

Kuru, M. 1979. The freshwater fish of South-Eastern Turkey-2 (Euphrates-Tigris system). Hacettepe Bull. Nat. Sci. Eng., 7(8): 105-114

Kuru, M. 1980. Key to the inland water fishes of Turkey, Part III, Hacettepe Bull. Nat. Sci. Eng., 9: 123-133.

Laevastu, T. 1965. Manual of methods in fisheries biology. FAO Manuals Fish. Sci., 4(9): 37-45.

Le Creen, E. D. 1951. The length-weight relationship and seasonal cycle in gonad weight and condition in perch (Perca fluviatilis). J. Anim. Ecol., 20: 201-219. DOI: 10.2 $307 / 1540$.

Maso, G., Latorre, D., Tarkan, A. S., Vila-Gispert, A. and Almeida, D. 2016. Inter-population plasticity in growth and reproduction of invasive bleak, Alburnus alburnus (Cyprinidae, Actinopterygii), in north-eastern Iberian Peninsula. Folia Zoologica, 65(1): 10-14. doi.org/10.25225/ fozo.v65.i1.a3.2016.

Mousavi-Sabet, H., Abdollahpour, S., Salehi-Farsani, A., Vatandoust, S., Langroudi, H. F., Jamalzade, H. R. and Nasrollahzadeh, A. 2013. Length-weight and length-length relationships and condition factor of Alburnus mossulensis (Heckel, 1843) from the Persian Gulf basin. AACL Bioflux 6(4): 297-302.

Nikolsky, G. V. 1963. The ecology of fishes. Academic Press, London and New York, $352 \mathrm{pp}$.

Oymak, S. A. 2000. Ataturk Baraj Golu'nde yaşayan Chondrostoma regium (Heckel, 1843)'un buyume ozellikleri. Turkish J. Zool., 34: 41-50.

Oymak, S. A., Unlu, E., Parmaksiz, A. and Dogan, N. 2011 A study on the age, growth and reproduction of Aspius vorax (Heckel, 1843) (Cyprinidae) in Ataturk Dam Lake (Euphrates River), Turkey. Turkish J. Fish. Aquat. Sci., 11(2): 217-225. DOI: 10.4194/trjfas.2011.0206.

Ozdemir, N., Sen, D., Duman, E. and Yapar, A. 1993. Keban Baraj Golu'nde yasayan Chalcalburnus mossulensis (Heckel, 1843)'de yas-boy, yas-agırlık ve boy-agırlık iliksileri uzerine bir arastırma, Dogu Anadolu Bolgesi I. (1993) ve II. (1995) Su Urunleri Sempozyumu. Erzurum, p. $13-21$ 
Parsa Khanghah, A., Mojazi Amiri, B., Sharifpour, I., Jalali Jafari, B. and Motalebi, A. A. 2011. Gonads tissue changes of Chalcalburnus mossulensis (Heckel, 1843) infected by Ligula intestinalis (Cestoda). Iranian J. Fish. Sci., 10(1): 85-94.

Pollux, B. J. A., Pollux, P. M. J., Korosi, A., Verberk, W. C. E. P. and Van der Velde, G. 2006. Reproduction, growth and migration of fishes in a regulated lowland tributary: potential recruitment to the river Meuse. Hydrobiologia, 565: 105-120. DOI: 10.1007/s10750-005-1908-4.

Ricker, W. E. 1968. Methods for assessment of fish production in fresh waters. International Biological Programme No. 3 , Black-Well Scientific Publications, London, 313 pp.

Stavrescu-Bedivan, M. M., Aioanei, F. T. and Scaeţeanu, G. V. 2017. Length-weight relationships and condition factor of 11 fish species from the Timis River, Western Romania. Poljoprivreda i Sumarstvo, 63(4): 281-285.

Tesch, F. W. 1968. Age and growth in methods for assessment of fishes production. In: Ricer, W. E. (Ed.), Methods for assessment of fish production in freshwater, IBP Handbook, Blackwell Science Publication, London, p. 93-123.

Turkmen, M. and Akyurt, I. 2000. The population structure and growth properties of Chalcalburnus mossulensis (Heckel, 1843) caught from Askale region of River Karasu. Turkish J. Biol., 24(1): 95-111.

Uckun, A. A. and Gokce, D. 2014. Assessing age, growth and reproduction of Alburnus mossulensis and Acanthobrama marmid (Cyprinidae) populations in Karakaya Dam Lake (Turkey). Turkish J. Zool., 39(1): 1-14. DOI: 10.3906/zoo1211-13.

Unlu, E. 1991. A study on the biological characteristics of Capoeta trutta (Heckel, 1843) living in the Tigris River, Turkey. Turkish J. Zool., 15: 22-38.

Unlu, E. 2014. Fisheries and aquaculture in the Euphrates and Tigris River in Turkey. Report of the Expert Meeting on the Review of Fisheries and Aquaculture Activities in the Tigris Euphrates Basin, Erbil, Iraq, 11-12 November 2012. FAO Fisheries and Aquaculture Report No: 1079. Food and Agricultural Organisation, Rome.

Unlu, E., Balci, K. and Akbayın, H. 1994. Some biological characteristics of the Achantobrama marmid (Heckel, 1843) in the Tigris River (Turkey). Turkish J. Zool., 18: 131-139.

Yildirim, A., Haliloglu, H. I., Erdogan, O. and Turkmen, M. 2007. Some reproduction characteristics of Chalcalburnus mossulensis (Heckel, 1843) inhabiting the Karasu River (Erzurum, Turkey). Turkish J. Zool., 31(2): 193-200.

Yildirim, A., Haliloglu, H. I., Turkmen, M. and Erdogan, O. 2003. Age and growth characteristics of Chalcalburnus mossulensis (Heckel, 1843) living in Karasu River (Erzurum-Turkey). Turkish J. Vet. Anim. Sci., 27(5): 1091-1096. 